Fastabiq: Jurnal Studi Islam

ISSN 2723-0228

Vol. 2 No. 1 Bulan Juni Tahun 2021

Halaman: $45-61$

\title{
DIGITALISASI DAKWAH SEBAGAI UPAYA MEMBANGUN PERADABAN BARU ISLAM DI MASA PANDEMI COVID-19
}

\author{
DOI: https://doi.org/10.47281/fas.v2i1.33
}

\author{
Muhammad Himmatur Riza', Vika Rachmania Hidayah² \\ Universitas Islam Negeri Walisongo Semarang ${ }^{1,2}$ \\ $\underline{\text { muhammadhimmaturriza@gmail.com }}$, $\underline{\text { rachmaniavika@gmail.com }}{ }^{2}$
}

\begin{abstract}
The Covid-19 pandemic has plagued all over the world. Many aspects of the social order have changed including da'wah activities. The development and existence of technology and restrictions on various religious activities during the Covid-19 pandemic are challenges and opportunities in da'wah activities. Research conducted is literature research that is by collecting data from various sources of references that already exist. The result of this research indicates that the speaker is required to have mastery in the field of technology and continuously to upgrade soft skills to preach in this era. The method that must be modern and practical dawah material becomes a bargaining value that is in demand by the community. This provides an opportunity for dai to document all forms of activities that are da'wah and can also publish muslims and the dynamics of their developing lives. Dai's role must be able to adapt and compete with the globalization of information technology that is already rapidly evolving and liberally controlled by the west, so as to build a new civilization of the face of Islam in the Islamic preaching activities.
\end{abstract}

Keywords: Digitization of Da'wah, Covid-19 Pandemic, Islamic Civilization.

\begin{abstract}
Abstrak
Pandemi Covid-19 telah mewabah dunia. Banyak aspek tatanan kehidupan sosial mengalami perubahan termasuk dalam kegiatan dakwah. Adanya perkembangan dan keberadaan teknologi serta pembatasan berbagai kegiatan keagamaan di masa pandemi Covid-19 menjadi tantangan dan peluang dalam kegiatan dakwah. Penelitian ini dilakukan dengan berbasis data kepustakaan yaitu dengan mengumpulkan data dari berbagai sumber referensi yang sudah ada. Hasil dari penelitian ini menunjukkan bahwa dai atau penceramah dituntut untuk memiliki penguasaan dibidang teknologi dan terus menerus untuk mengupgrade soft skill guna mampu berdakwah di era sekarang ini. Metode yang harus dimodernisasi dan materi dakwah yang praktis menjadi nilai tawar yang diminati oleh masyarakat. Hal ini memberikan peluang bagi para dai untuk mendokumentasikan segala bentuk kegiatan yang bersifat dakwah dan juga dapat mempublikasikan umat islam beserta dinamika kehidupannya yang sedang berkembang. Peran dai harus mampu beradaptasi dan bersaing dengan globalisasi teknologi informasi yang dikuasai yang sudah secara pesat berkembang dan dikuasai secara liberal oleh barat, sehingga mampu membangun peradaban baru wajah Islam dalam berdakwah.
\end{abstract}

Kata kunci: Digitalisasi Dakwah, Pandemi Covid-19, Peradaban Islam. 


\section{Fastabiq: Jurnal Studi Islam \\ ISSN 2723-0228}

Vol. 2 No. 1 Bulan Juni Tahun 2021

\section{PENDAHULUAN}

COVID-19 yang melanda dunia ikut mempengaruhi sektor keagamaan yang pada akhirnya mengalihkan dakwah dari ruang tradisional ke ruang digital. ${ }^{1}$ Pembatasan kegiatan selama pandemi COVID-19 juga berdampak pada kegiatan keagamaan di masyarakat. Digitalisasi dakwah yang berlangsung akibat pandemi COVID-19 telah menciptakan fenomena baru dalam tradisi dakwah di Indonesia. Diseminasi dan transfer pengetahuan agama yang pada awalnya dipegang penuh oleh otoritas keagamaan seperti kiai dan tokoh agama kini berubah dengan adanya media digital. Pergeseran kecenderungan dakwah dari tradisional ke digital sekarang begitu kentara. ${ }^{2}$

Dengan bantuan new-technology, dakwah dapat tetap berjalan. Berdasarkan penggunaan teknologi, metode dakwah dapat diklasifikasikan ke dalam tiga jenis, yaitu dakwah konvensional, teledakwah, dan e-dakwah. Dakwah konvensional merupakan dakwah yang dilakukan dengan pertemuan secara langsung atau face to face antara dai dan audien. Perkembangan selanjutnya berupa tele-dakwah, yaitu dakwah melalui teknologi komunikasi dan media massa maupun cetak, radio, serta televisi. Kemudian yang teranyar, muncul e-dakwah, yaitu dakwah dengan bantuan internet. ${ }^{2}$ New media atau internet memberikan peluang besar bagi kegiatan dakwah karena internet memungkinkan setiap orang dengan mudah mendapatkan informasi dengan cepat dan real time.

Teknologi informasi dan komunikasi yang terus berkembang secara cepat menjadikan tatanan berubah di sejumlah kegiatan, termasuk juga dalam praktik berdakwah. ${ }^{3}$ Kehadiran teknologi informasi ini dapat menjadi solusi berdakwah khususnya selama masa pandemi Covid-19. la dapat menjadi solusi untuk tetap dapat memperkuat eksistensi dakwah meski berhadapan dengan tantangan masa pandemi Covid-19, sekaligus untuk menyesuaikan diri terhadap tuntutan serta kebutuhan zaman.

Fasilitas teknologi informasi dalam proses pengembangan dakwah sangat penting diaktualisasikan khususnya dengan menggunakan media digital. Ini sangat dimungkinkan terutama karena semakin akrabnya masyarakat kita dengan dunia digital. Berdasarkan hasil riset We Are Social, terdapat 175,4 juta pengguna internet di Indonesia pada tahun 2020. Berdasarkan riset ini, terdapat kenaikan $17 \%$ atau 25 juta dibanding pengguna sebelumnya. Jika dibandinkan, jumlah 175,4 juta pengguna internet dari sebanyak 272,1 juta jiwa populasi di Indonesia, yang berarti terdapat $64 \%$, atau setengah penduduk Indonesia telah terjamah dan merasakan akses dunia maya. ${ }^{4}$ Teknologi informasi, selain sebagai sarana media dakwah melalui media sosial, dapat juga digunakan untuk berkomunikasi antar individu yang lain untuk menyampaikan dakwah. Dengan demikian, urgensi digitalisasi dalam berdakwah menjadi hal yang tidak dapat terpisahkan dalam kehidupan bermasyarakat dalam dunia maya. Pentingnya menjadi sebuah wacana pemikiran tentang media dakwah di era digital untuk memaksimalkan syiar kebaikan terlebih pada masa pendemi Covid-19.

Kajian ini memaparkan sejumlah tinjauan dan analisis dalam melihat dan membahas teknologi informasi dan komunikasi sebagai media dakwah di masa pandemi Covid-19. Digitalisasi dakwah memberikan peluang bagi para dai untuk mendokumentasikan dan mempublikasikan serangkaian DIGITALISASI DAKWAH SEBAGAI UPAYA MEMBANGUN PERADABAN BARU ISLAM 


\section{Fastabiq: Jurnal Studi Islam \\ ISSN 2723-0228}

Vol. 2 No. 1 Bulan Juni Tahun 2021

kegiatan untuk mengajak masyarakat dalam kebaikan (berdakwah) dan memberikan teladan-teladan mengenai dinamika kehidupan umat muslim sehingga perkembangannya selalu dapat beradaptasi dan bersaing dengan era yang telah dikuasai secara liberal oleh barat. Dengan demikian, pemanfaatan teknologi informasi dapat maksimal untuk membangun peradaban baru wajah Islam dalam berdakwah, menyebarluaskan ajaran Islam yang rahmatan lil 'alamin.

\section{METODE PENELITIAN}

Penelitian ini dilakukan dengan menggunakan metode penelitian kepustakaan atau library research, yakni penelitian yang dilakukan melalui mengumpulkan data atau karya tulis ilmiah yang relevan dengan obyek penelitian, atau pengumpulan data yang bersifat kepustakaan, atau telaah yang dilaksanakan untuk memecahkan suatu masalah dengan mendasarkan secara spesifik pada penelaahan kritis dan mendalam terhadap bahan-bahan pustaka yang relevan.

Adapun pendekatan yang digunakan dalam penelitian ini adalah pendekatan historis. Pendekatan historis yang digunakan di sini dimaksudkan untuk meneliti sejarah metode dakwah pada zaman Rasulullah SAW dan Sahabat Nabi. Karena bagaimanapun, metode dakwah zaman Rasulullah SAW dan para sahabat Nabi selalu dijadikan contoh keberhasilan dakwah pada saat ini sebagai upaya membangun peradaban baru Islam di masa pandemi Covid-19.

\section{HASIL DAN PEMBAHASAN}

\section{Pengertian Digitalisasi Dakwah}

Muhammad Rajab Asy-Syatiwi memberikan definisi dakwah sebagai ilmu yang digunakan agar dapat memahami keberagaman usaha yang ditunjukan kepada penyebarluasan agama Islam serta termasuk yang ada di dalamnya membahas mengenai syariat, akidah maupun akhlaq. ${ }^{5} \mathrm{Al}-$ Qur'an telah menyebutkan sebanyak 198 kali kata dakwah yang akar katanya terdiri dari dal, 'ain, dan wawu yang mencerminkan beragamnya bentuk dan makna. Terdapat dua arti sekaligus mengenai ramfikasi dakwah dan makna katanya yaitu yang hubungannya vertikal (menyembah dan doa) dan yang hubungannya perihal seruan, ajakan, panggilan, permintaan, undangan dan harapan (horizontal). ${ }^{6}$

Secara etimologis, dakwah dalam alquran merupakan kata yang bermakna tidak selamanya digunakan untuk mengajak kepada kebaikan. Namun dapat juga digunakan sebagai ajakan kepada keburukan. Q.S al-Baqarah (2) ayat 221 telah mencerminkan bahwa dakwah sebagai kata yang digunakan untuk menyerukan atau ajakan pada kebaikan. Secara leterlek, ayat tersebut mempunyai arti:

“.... Allah mengajak ke surga dan ampunan dengan izin-Nya. (Allah) menerangkan ayat-ayat-Nya (perintah-perintah-Nya) kepada manusia supaya mereka mengambil pelajaran"7

Sedangkan dakwah sebagai kata yang dipakai untuk mengajak pada kejahatan maupun pada keburukan disebutkan pada QS fathir (35) ayat 6 dengan arti sebagai berikut: 


\section{Fastabiq: Jurnal Studi Islam \\ ISSN 2723-0228}

Vol. 2 No. 1 Bulan Juni Tahun 2021

"Sesungguhnya syaitan itu adalah musuh bagimu, maka anggaplah ia musuh(mu), karena sesungguhnya syaitan-syaitan itu hanya mengajak golongannya supaya mereka menjadi penghuni neraka yang menyala-nyala." ${ }^{8}$

Secara terminologi, dakwah disini dimaknai sebagai usaha untuk menyerukan maupun mengajak umat manusia supaya tetap berjalan pada koridor yang benar (islam) sesuai dengan fitrah secara integral, dengan menggunakan jalur lisan maupun tulisan atau bahkan menggunakan perbuatan yang bertujuan untuk menyampaikan sebuah nilai kebaikan dan kebenaran (al khair). ${ }^{9}$ Merujuk pada makna Al-Islam, dakwah merupakan suatu aktivitas sehari-hari yang ada di kehidupan budaya maupun sosial, yang berupaya untuk mencegah serta menjauhkan dari suatu hal yang dilarang untuk dilakukan oleh hati nurani sehingga dapat terciptanya umat pilihan (khair ummah).

Syukriadi Sambas sebagaimana yang dikutip oleh Abdul Basit menyatakan bahwa dakwah merupakan proses internalisasi, transmisi, institusionalisasi, difusi, dan transformasi Islam dengan mencampurkan unsur da'i, media, pesan, mad'u, respon, metode dan tujuan, serta dimensi ruang dan waktu guna terciptanya kehidupan khazanah, keselamatan dan cahaya di dunia maupun di akhirat. ${ }^{10}$ Sedangkan menurut Amrulloh Ahmad, dakwah adalah cara tertentu untuk kepentingan proses aktualisasi imani (teologis) yang dilakukan dalam bentuk aktivitas manusia beriman dalam bidang kemasyarakatan dengan diterapkan secara teratur agar dapat meracuni cara berfikir, merasa, bersikap dan bertindak manusia guna terwujudnya ajaran Islam dalam semua aspek kehidupan. ${ }^{11}$

Melihat penjabaran di atas, dakwah dapat kita pahami sebagai suatu tindakan atau langkah yang dipakai guna menyebarkan nilai-nilai keislaman. Jika metode dakwah digunakan dengan mengedepankan aspek humanisme, maka akan tercipta islam yang rahmatan lil 'alamin dengan mengimplementasikannya ke dalam kehidupan sehari-hari. Kemudian, dakwah juga merupakan sebuah nilai kultural dan transendental. Nilai kultural yang dimaksud adalah dengan bersinggungan kearifan lokal dan sistem budaya yang ada di masing-masing daerah agar tercipta proses akulturasi budaya yang dinamis. Sedangkan nilai transendental dalam dakwah merupakan aktivitas menyeru dengan menitikberatkan kepada hal yang bersifat teologis (ketuhanan), sehingga semuanya bermuara pada ajakan bertuhan dan meyakini seluruh ciptaan tuhan.

Selain yang dijabarkan di atas, dakwah juga dapat diartikan sebagai upaya ataupun proses ajakan untuk berbuat baik dan selalu produktif. Karena pada hakikatnya produktivitas dari seorang muslim sekarang ini harus terus ditingkatkan agar dapat berkembang semaksimal mungkin. Dalam pengertian bahwa seorang muslim harus dapat mempunyai kemampuan dalam berkompetisi dengan yang lain dan harus mempunyai karakter yang kuat dan tangguh. Di sisi lain, dakwah juga merupakan ilmu pengetahuan. Jika dimaknai sebagai ilmu pengetahuan maka dakwah mempunyai sisi psikologis, filosofis, etnografis maupun historis. Sehingga pada tingkat universitas banyak terdapat fakultas-fakultas dakwah dengan mengkaji dinamika dakwah Islam, agar dapat memunculkan sarjana muslim yang mempunyai produktivitas dan sikap toleran terhadap sesama. 


\section{Fastabiq: Jurnal Studi Islam \\ ISSN 2723-0228}

Vol. 2 No. 1 Bulan Juni Tahun 2021

Dakwah dapat berkonotasi positif ataupun negatif. Dakwah jika dilakukan dengan niat kebaikan maka aktivitasnya disampaikan guna mengajak orang lain untuk menjadi lebih baik dan terpuji dari sebelumnya. Sedangkan jika bermakna atau mengerucut kepada aktivitas negatif maka dalam ajakannya akan menyerukan perbuatan-perbuatan yang dapat membahayakan orang lain, seperti berbuat dzolim dan bahkan dapat merusak alam semesta ini.

Berubahnya zaman, dakwah yang dulu hanya sebatas melalui forum secara langsung bertatap muka kini telah berpindah menjadi dakwah yang dilakukan secara digital. Hal ini didasarkan pada hasil riset Platform manajemen media sosial HootSuite dan agensi marketing sosial We Are Social yang bertajuk "Global Digital Reports 2020" yang menyatakan bahwa hampir 64 persen penduduk Indonesia sudah terkoneksi dengan jaringan internet/digital. Sehingga dakwah yang dilakukan secara digital menjadi sangat diperlukan untuk memenuhi kebutuhan rohani masyarakat sekarang apalagi di tengah pandemi.

Dakwah saat ini sudah tidak popular lagi jika hanya mengandalkan media lisan. Mimbarmimbar yang sebelumnya menjadi andalan penyampaian ajaran kini sudah bukan zamannya lagi. Adanya pandemi, mengharuskan masyarakat untuk tetap tinggal di rumah sebagai langkah untuk memutus penyebaran virus. Hal tersebut menjadikan semua aktivitas masyarakat dilakukan secara daring atau virtual. Media digital merupakan alternatif yang tidak bisa ditawar-tawar lagi untuk melaksanakan kegiatan dakwah agar tetap survive melayani masyarakat. Dengan demikian adanya digitalisasi dakwah menjadi sebuah upaya untuk membangun peradaban baru ditengah pandemi saat ini.

Digitalisasi dakwah adalah proses mengubah informasi dakwah dari format analog menjadi format digital agar mudah diproduksi, disimpan dan disebarluaskan kepada masyarakat. Dengan didukung oleh teknologi yang semakin melekat dalam kehidupan sehari-hari menjadikan digitalisasi dakwah sangat perlu dilakukan. Melalui dakwah dengan didukung oleh teknologi yang cakap memberikan manfaat positif untuk masyarakat agar tetap dapat bertemu, berbicara, dan berinteraksi secara virtual dengan kyai, nyai, atau ustadz maupun ustadzah. Keuntungan yang diperoleh dengan adanya digitalisasi dakwah yaitu efisien dan efektif. Kegiatan dakwah akan lebih efisien karena melalui media digital, maka tidak membutuhkan waktu dan tempat.

Pada aspek efektif, dengan mengacu pada efek yang dihasilkan melalui media digital. Digitalisasi dakwah akan lebih efektif dari pada dakwah secara lisan melalui mimbar. Kesempatan bertemu muka langsung yang terbatas, maka dengan adanya media digital dakwah dapat masuk ke rumah-rumah masyarakat dalam tempo dan tempat yang tidak terbatas. Dakwah melalui digital akan dapat menjangkau jumlah jamaah yang lebih besar di berbagai pelosok geografis yang semakin luas dan juga waktu yang fleksibel tergantung kebutuhan atau keluangan waktu dari masing-masing masyrakatnya.

\section{Konsep Digitalisasi Dakwah}

Digitalisasi dakwah adalah sebuah konsep baru yang memberikan nuansa islami diseluruh media digital. Namuh dengan pesatnya perkembangan teknologi saat ini, media digital dapat 


\section{Fastabiq: Jurnal Studi Islam \\ ISSN 2723-0228}

Vol. 2 No. 1 Bulan Juni Tahun 2021

diakses oleh siapa saja dan dalam kurun waktu kapan saja. Sehingga konten-konten dakwah di media digital dapat diunggah oleh kelompok masyarakat siapa asaja dan dimana saja. Dengan demikian, perlu adanya filtrasi dari masyarakat untuk memilih akun media digital yang mampu memberikan konten ajaran islam ramah atau moderat. Konsep dakwah dalam media digital tidak pernah terlepas dari konsep dakwah secara langsung di mimbar. Berikut adalah konsep dakwah yang perlu dipahami di era digitalisasi saat ini.

\section{a. Dakwah Sufistik}

Sufistik adalah istilah yang diambil dari kata sufi ataupun tasawuf. Dakwah ini merupakan dakwah yang dilakukan oleh para sufi. Jika ditinjau secara etimologi, Ahlu al-Suffah merupakan konotasi dari istilah tasawuf. Ahlu al-Suffah sendiri memiliki arti sekelompok orang pada masa Rasulullah SAW, mereka yang mengabdikan dirinya, mengabdikan hidupnya semata untuk beribadah kepada Allah swt sehingga mereka hidup pada serambi-serambi masjid Nabawi. Shafa adalah adalah dari kata tasawuf, yang menjadi sebutan untuk mereka yang "bersih" maupun "suci", yang selalu menyucikan diri di hadapan Allah SWT. Orang-orang Bani Shufah merupakan orang-orang yang dinisbahkan sebagai orang-orang yang mengabdikan dirinya untuk keperluan ka'bah dan mereka juga sudah melakukan hal tersebut sebelum rasulullah SAW diutus oleh Allah menjadi rasul. Orang-orang yang ketika sholat berada pada shaf depan juga dinobatkan sebagai orang tasawuf. Sedangkan jika dilihat dari istilah Yunan yaitu Sovia, tasawuf diartikan sebagai kebijaksanaan atau filsafat. ${ }^{12}$ Barmawie Umarie menyatakan bahwa wazan tafa'ul, yaitu tafa'ala-yatafa' 'ala-tafa'ulan dengan mauzun: tashawwafa-yatashawwafu-tashawwufan merupakan aasal dari kata tasawuf. ${ }^{13}$

Dakwah sufistik dilakukan dengan konsep dakwah yang dilakukan oleh Rasulullah SAW. Diantaranya:

1) Menyampaikan hal-hal kebenaran terhadap orang-orang terdekatnya terlebih dahulu contohnya kepada keluarganya (bi al-Lisan);

2) Mengajarkan ketauhidan pada umatnya melalui kehidupan sehari-hari (bi al-Kalam);

3) Umat diberikan contoh perbuatan atau adab (akhlak) mulia yang baik (bi al-Hal);

4) Sahabat dan para musuh dikirimkan surat (bi al-Qalam). ${ }^{14}$

Dakwah para sufi ini sangat menekankan perihal kebenaran yang ada dalam mata hati untuk upaya dalam mendalami suatu hal yang sudah tersirat mupun tersirat pada syari'at, sebagai amanah untuk melaksanakan perintah Allah SWT. Sehigga itu yang menyebabkan orang-orang sufi telah membagi agama dalam dua hal golongan, yaitu bid'ah sayyi'ah (bid'ah yang buruk) dan bid'ah hasanah (bid'ah yang baik). ${ }^{15}$

\section{b. Dakwah Sosial}

Perkembangan zaman yang semakin pesat, menjadikan akses melakukan apa saja menjadi sangat mudah. Tidak terbatasnya informasi di media digital membuat masyarakat semakin membutuhkan konten islami untuk memenuhi kehidupan rohaninya. Di masa pandemi saat ini, dakwah menjadi kebutuhan penting untuk masyarakat agar tetap waras di tengah 


\section{Fastabiq: Jurnal Studi Islam \\ ISSN 2723-0228}

Vol. 2 No. 1 Bulan Juni Tahun 2021

gejolak keadaan yang tidak menentu. Digitalisasi dakwah dalam prespektif sosial merupakan sebuah dakwah yang menggunakan dialog nilai-nilai kehidupan kelompok maupun indvidu, prinsip, ideologi dan interaksi dengan pendekatan psikologis melalui media digital.

Ketika berdakwah pada masyarakat urban, seorang da'i dituntut untuk mempunyai kemampuan untuk observasi juga riset agar nantinya materi yang disampaikan oleh seorang da'i dapat dipahami oleh masyarakat dan sesuai dengan kondisi kebutuhan masyarakat saat pandemi. Disamping itu, cara-cara yang digunakan juga harus menyesuaian kondisi masyarakat sehingga da'i juga dituntut untuk dapat menguasai teknologi dan selalu mengerti perkembangannya, hal ini diperlukan agar pesan yang disampaikan dapat beradaptasi sesuai system dan sosial di masyarakat yang sudah progresif dan massif. ${ }^{16}$

Dakwah jika melihat substansial dan konteks sosialnya, bukan hanya memiliki tujuan untuk menguatkan ketauhidan seseorang saja dalam artian adalah hubungan vertikal dengan Allah SWT, melainkan terdapat juga pesan yang cakupannya mengenai hubungan baik terhadap sesame manusia atau dalam artian adalah hubungan horizontal dengan samayarakat sekitar yang harus dijalankan sesuai dengan syariat atau kehendak Allah swt. Kehendak tersebut memberikan pandangan untuk kita dapat membentuk umat atau masyarakat yang senantiasa mengejar nilai-nilai utama dan turut berjuang untuk menegakkan keadilan sosial. Sehingga pandangan (visi) tersebut dapat menginsiprasi kita agar dapat mengubah dunia yang ada di sekelilingnya sesuai dengan kehendak Allah.

Dakwah Islam juga harus mengajarkan prinsip keadilan distributive (distributive justice). Jika meminjam istilah Abdul Munir Mulkhan "sekelompok masyarakat tidak diperkenankan terlalu kaya, sementara kelompok lainnya menderita kemiskinan yang bertentangan dengan harkat kemanusiaan"17 Prespektif ilmu dakwah untuk menyikapi perubahan sosial, bukan hanya sekedar studi fenomenologis yang terbebas dari nilai-nilai melainkan lebih dari itu. Perubahan sosial sangat penting dalam ilmu dakwah karena perubahan disini dapat diartikan dengan bergesernya nilai-nilai kebaikan menuju kemungkaran, begitupun sebaliknya dari kemungkaran menuju kebaikan. Dalam al-Qur'an surat al-Baqarah ayat 257 yang artinya:

"Allah adalah pelindung orang-orang yang beriman: Dia mengeluarkan mereka dari kegelapan (kekafiran) kepada cahaya (Iman). Dan orang-orang kafir, pelindungnya adalah syaitan yang mengeluarkan merea dari cahaya kepada kegelapan (kekafiran).."18

Ayat tersebut menggambarkan 2 (dua) dimensi perubahan yang dapat dipahami dan dianalisis berdasarkan ilmu dakwah yaitu perubahan dengan pola pusaran luar dan perubahan dengan pola pusaran ke dalam. Pergeseran pola hidup manusia merupakan perubahan ke luar yang meliputi pola pikir, pola perilaku yang memang cenderung menjauh dari titik koordinat (kebenaran). Pernyataan ini juga masih berhubungan dengan hadits yang menyebutkan bahwa semua manusia dilahirkan dalam kondisi fitrah. Fitrah yang dimaksud disini bukanlah suci atau bersih tanpa membawa dosa warisan. Namun fitrah yang dimaksud adalah titik sentral (central point) yang dijadikan sebagai bagian titik koordinat kehidupan manusia sebagai makhluk sosial yang membaur ditengah-tengah masyarakat. Titik koordinat manusia pada hakekatnya 


\section{Fastabiq: Jurnal Studi Islam \\ ISSN 2723-0228}

Vol. 2 No. 1 Bulan Juni Tahun 2021

membawa nilai-nilai kebenaran, namun karena pergaulan lingkungan dan faktor-faktor lingkungan yang lain menjadikan manusia jauh dari titik koordinat tersebut. ${ }^{19}$ Dengan demikian, dakwah sangat diperlukan untuk selalu mengontrol manusia tetap berada dalam titik koordinat. Tetap dapat berada dalam jalan kebenaran yang diridhoi Allah SWT.

\section{c. Dakwah Kultural}

Pandemi Covid-19 telah membatasi interaksi masyarakat untuk berkumpul dan bercengkrama. Pandemi telah mengubah sebuah kultur masyarakat yang biasanya dilakukan perkumpulan majelis-majelis di sudut masjid mengharuskan tetap tinggal di rumah guna keselamatan diri dan orang lain. Dakwah merupakan proses komunikasi efektif dan terusmenerus dengan mengunakan cara-cara ilmiah dan sarana efisien yang bersifat umum dan rasional. Komunikasi adalah salah satu metode dakwah yang diterapkan oleh Rasulullah kepada para sahabatnya. Dengan adanya komunikasi, maka dapat mampu mencapai targettarget yang diinginkan. Dakwah dengan menggunakan komunikasi yang baik maka nilai-nilai illahi dalam kehidupan akan selalu menyertai. ${ }^{20}$

Komunikasi yang baik sangat dibutuhkan dalam berdakwah. Selain itu, media-media berdakwah juga tidak kalah pentingnya untuk pesan yang ingin disampaikan dapat diterima oleh masyarakat. Sebagai contoh media komunikasi dakwah yang digunakan oleh Rasulullah SAW yaitu dengan menerapkan pesan berantai ".... maka hendaklah yang hadir menyampaikan kepada yang tidak hadir" (al-hadits). Dengan demikian terjadilah pesan secara berantai dari mulut ke mulut, karena Rasulullah SAW selalu memberikan arahan-arahan yang komunikatif dan efektif sebagai bentuk pesan strategi dakwahnya. ${ }^{21}$

Memaknai dari hadist di atas, dakwah sebagai fenomena kultural yang mempunyai relevansi pada pendekatan dan metodologi dakwah. Metode dakwahnyapun disesuaikan dengan hal-hal ataupun kebudayaan yang sudah ada di masyarakat sekitar dan nilai-nilai yang sudah melekat di daerah tersebut. Sehingga metode dakwah yang diterapkan di perkotaan pastinya berbeda dengan metode dakwah yang diterapkan di pedesaan. Dakwah yang dilakukan di masyarakat pedesaan lebih kepada dakwah metode tradisional yaitu dengan pendekatan dan metodologi yang khusus menyesuaikan budaya yang melekat di masyarakat seperti halnya sebuah kesenian daerah. Dakwah yang dilakukan di pedesaan lebih kepada mengangkat isu ataupun tema yang mengarah kepada pembahasan vertikal (tema-tema langit, surga, neraka, ancaman dan hiburan). ${ }^{22}$ Sedangkan dakwah yang disampaikan kepada masyarakat perkotaan lebih kepada tema-tema horizontal (tasawuf: hubungan baik terhadap sesama, sikap toleransi, tidak mendeskriminasikan satu sama lain, dII).

Dakwah kultural merupakan dakwah yang menekankan pada pendekatan Islam kultural. ${ }^{23}$ Menurut Sakareeya Bungo: "Islam kultural adalah salah satu pendekatan yang berusaha meninjau kembali kaitan doktrinal yang formal antara Islam dan politik atau Islam dan negara..." ${ }^{24}$ Dalah hal ini berarti lebih kepada apliktif menyesuaikan dengan kondisi daerah dan kondisi masyarakat sekitar. Seperti halnya dakwahnya para wali yang kaya akan nuansa dinamika kehidupan, sehingga prosesnyapun berjalan dengan dinamis menyelaraskan kondisi 


\section{Fastabiq: Jurnal Studi Islam \\ ISSN 2723-0228}

Vol. 2 No. 1 Bulan Juni Tahun 2021

lingkungan masyarakat yang menjadi sasaran berdakwah. Dengan kondisi yang dinamis seperti inilah mempunyai sebuah fungsi untuk mengajak perubahan masyarakat kea rah yang lebih baik serta memberikan efek kepada pendakwahnya sendiri untuk dapat merubah dirinya sendiri agar dapat memberikan contoh kepada masyarakat.

Media yang berperan penting untuk melakukan pelaksanaan kegiatan religi adalah kesenian. Dengan adanya seni maka akan memberikan daya tarik yang mengesankan di hati dan pikiran pada setiap pendengar dan penontonnya. Sehingga kesenian adalah metode yang efektif untuk digunakan dalam berdakwah. Melalui kesenian, seorang pendakwah dapat memberikan pesan-pesan yang menjadi tujuan dakwah, sehingga kesenian bukan hanya sebatas diartikan sebagai hiburan semata. Untuk orang-orang yang gemar menikmati sebuah kesenian pastinya akan menghayati dan tergerak serta tergugah dengan pesan-pesan apa yang disampaikan dalam seni tersebut. ${ }^{25}$

Media dakwah melalui seni mempunyai banyak keunggulan. Karena seni tidak lepas dari perkara keindahan, kesenangan dan segala sesuatu yang menyenangkan dan mempesoan bagi penikmatnya. Adapun menikmati sebuah keindahan dan sebuah kesenangan merupakan kegemaran dari fitrah manusia yang dianugerahkan Allah SWT kepada manusia. Dalam sejarah peradaban manusia belum ada dijumpai seseoran yang sengaja menjauhkan diri dari berbagai kesenian, lebih khususnya seni tari dan musik. Bahkan pendakwah terdahulu (para wali) dalam menyiarkan agama Islam di Nusantara menggunakan metode dakwah dengan pendekatan kesenian. Dan hasil yang diperoleh tentunya sangat efektif menggunakan dakwah dengan metode kesenian. Hal ini yang menyebabkan Islam masuk ke Nusantara dengan aman, indah dan damai menggunakan seni dan budaya tanpa menggunakan peperangan ataupun pertumpah darahan. ${ }^{26}$

Dakwah kultural sudah sepatutnya dapat beradaptasi dan menjawab tantangan zaman yang selalu berkembang. Maka dari itu, perlu untuk saling bekerja secara harmonis bagi masyarakat, pegiat kesenian dan juga da'l untuk dapat membuat sebuah inovasi gagasan untuk merumuskan media dakwah yang mengandung nilai-niali keindahan dalam kesenian budaya. Dakwah Islam yang menggunakan metode seni musik cenderung diterima baik oleh kalangan masyarakat baik di perkotaan maupun pedesaan. Sehingga ini menjadi sebuah kesempatan yang besar untuk menggerakan individu atau kelompok masyarakat untuk berdakwah menggunakan kesenian musik.

Melalui media digital, dakwah tetap mempunyai ruhnya untuk terus bereksistensi membangun peradaban yang lebih baik lagi. Dakwah kultural sangat diperlukan di masa pandemi untuk menghibur masyarakat dengan disisipkan nilai-nilai keislaman. Melalui sebuah kesenian tari dan musik, masyarakat akan lebih menikmati kegiatan dakwah yang dilakukan. Adanya pandemi kebutuhan hiburan dan kerohanian masyarakat menjadi sebuah kebutuhan utama yang harus dipenuhi. Dengan bantuan media digital, kegiatan dakwah kultural dapat dinikmati oleh banyak orang tanpa harus berkerumun untuk menghadiri sebuah majelis. 


\section{Fastabiq: Jurnal Studi Islam \\ ISSN 2723-0228}

Vol. 2 No. 1 Bulan Juni Tahun 2021

\section{Digitalisasi Dakwah: Peradaban Baru Islam di Masa Pandemi Covid-19}

Digitalisasi dakwah telah menjadi alternatif pemenuhan kebutuhan kerohanian di masa pandemi saat ini. Jika mengingat kembali dakwah di era Rasulullah SAW, kegiatan dakwahnya cenderung dilakukan secara sembunyi-sembunyi. Rasulullah SAW tidak menunjukkan adanya gerakan dakwah kepada masyarakat luas sehingga situasi saat itu tetap tenang dan damai. Rasulullah SAW memilih dan menetapkan orang-orang yang diseru adalah mereka yang dinilai memiliki pengaruh di kalangan masyarakat Quraisy dan memiliki kecenderungan pada kebenaran. ${ }^{27}$ Tindakan baginda Muhammad SAW ketika melaksanakan dakwah selama dua periode yaitu Makkah dan Madinah merupakan sebuah garis besar kisah dakwah yang dapat dicontoh. Ketika Nabi Muhammad SAW diangkat sebagai rasul tahun 611, masuklah masa periode Makkah dengan strategi yang digunakan adalah sirriyah al-da'wah (dakwah secara rahasia) dan jahriyatu al-da'wah (dakwah secara terang-terangan). ${ }^{28}$

Masuknya Islam dan berkembangnya Islam di Indonesia diawali melalui jalur perdagangan yang dibawa oleh Gujarat di wilayah pesisir Sumatera. Hal ini dibuktikan dengan berdirinya Kerajaan Samudera Pasai di wilayah Aceh pada tahun XIII M. ${ }^{29}$ Mengenai dakwah dan penyebaran Islam di Indonesia, penyebar Islam yang sangat berpengaruh di Indonesia adalah Walisongo. Para wali berdakwah dengan memanfaatkan budaya setempat, misalnya yang dilakukan oleh Sunan Kalijaga, Sunan Kalijaga berdakwah dengan memanfaatkan gamelan dan wayang. Secara spesifik, pola dakwah Walisongo didasarkan pada pola pengelolaan dan pengembangan budaya masyarakat. Dalam hal ini, pengelolaan dan pengembangan budaya setempat sebagai kemasan pola dakwah dilakukan dengan memasukkan nilai-nilai kearifan lokal, universal dan ajaran Islam yang rahmatan lil'alamin. ${ }^{30}$

Dakwah Islam yang dilakukan secara santun dan tanpa menghilangkan warisan budaya lokal oleh Walisongo, memberikan pemahaman bahwa agama Islam dikenal sebagai agama yang menentramkan, mendamaikan dan membawa keselamatan. Kultur masyarakat yang masih menganut keyakinan nenek moyang berupa Animisme dan Dinamisme merupakan tantangan tersendiri untuk para wali dalam berdakwah. Dengan demikian, para Wali menerapkan strategi dakwah yang mampu diterima masyarakat, tanpa menghilangkan adat atau tradisi yang telah berlaku secara turun-temurun. Hal tersebut dianggap lebih efektif dan kondusif, agar Islam dapat diterima oleh masyarakat yang fanatik dengan ajaran nenek moyang.

Berubahnya era, menjadi tantangan dalam berdakwah juga berubah dari masa ke masa. Dakwah di era sekarang pastinya mempunyai tantangan yang berbeda dengan dakwah di era Walisongo. Era sekarang adalah era dimana teknologi serba canggih dan semuanya serba cepat serta efisien sehingga era sekarang tantangannya adalah bukan perihal bagaimana Islam dapat diterima oleh masyarakat, namun terlebih pada pemilihan konteks yang menarik dan dapat diterima oleh masyarakat dengan konteks Islam secara kaffah. Sebagai orang yang menganut agama Islam sudah sepatutunya melaksanakan Islam dengan memperhatikan kewajiban seorang yang beragama Islam. Selain itu, juga menjamin agama Islam dapat dianut oleh kaum muslim dengan tetap menjalankan segala perintah-Nya dan menjauhi segala larangan-Nya. 


\section{Fastabiq: Jurnal Studi Islam \\ ISSN 2723-0228}

Vol. 2 No. 1 Bulan Juni Tahun 2021

Aktivitas intelektual manusia dalam peradaban era sekarang menjadikan teknologi semakin maju dan kompleks. IImu pengetahuan yang sudah berkembang saat ini diantaranya dipacu oleh kegiatan intelektual manusia yang tidak mengenal batas waktu dan ruang. Umat Islam di era sekarang benar-benar dituntut untuk membuka mata perihal ilmu pengetahuan khususnya ilmu kemanusiaan. Dinamika pemikiran yang tidak dapat dikendalikan dan kegelisahan-kegelisahan intelektual yang muncul di dalamnya adalah tantangan untuk selalu berdakwah yang sesuai konteks permasalahan yang terjadi. ${ }^{31}$ Umat Islam harus tetap berupaya untuk mengikuti zaman yang berkembang ini dengan sangat berhati-hati sehinga tidak akan menyimpang dari koridor syariat dan Sunnah. Adanya teknologi yang menjadi media beragam, seharusnya digunakan dengan bijaksana sebagai sarana komunikasi dan berdakwah.

Generasi millennial atau Gen Y merupakan generasi yang akrab sekali dengan teknologi. Sehingga jika dakwah akan disampaikan melalui media teknologi, generasi millennial lah yang akan menjalankan. Generasi milenial atau Gen Y menurut Martin \& Tulgan adalah generasi yang lahir pada kisaran tahun 1978. Sementara menurut Howe \& Strauss, generasi milenial adalah generasi yang lahir pada tahun 1982. Hal tersebut terjadi karena adanya perbedaan skema yang digunakan untuk mengelompokkan urutan generasi karena peneliti-peneliti tersebut berasal dari Negara yang berbeda. ${ }^{32}$

Sekarang ini, jumlah populasi penduduk Indonesia yang berusaha antara 15-34 tahun atau $34,45 \%{ }^{33}$ Dan generasi millennial adalah generasi yang menduduki posisi tertinggi dalam demografi di Indonesia. Generasi millennial mempunyai keunggulan dalam penggunaan teknologi dan juga budaya pop terlebih pada musik. Generasi millennial ini juga mempunyai paparan penggunaan teknologi yang lebih banyak dari pada generasi sebelumnya. Sehingga generasi ini adalah generasi yang sangat dekat dan bersahabat dengan teknologi komunikasi. Diantara teknologi komunikasi adalah email, SMS, instant messaging, dan sejumlah media sosial seperti Twitter, Instagram, Facebook, dll. ${ }^{34}$

Alvara Research Center telah melakukan survei perihal kecenderungan yang dilakukan oleh generasi. Dari survei tersebut mendapatkan hasil bahwa generasi yang berusia 25-34 tahun mempunyai kecenderungan menyukai topik yang lebih variatif yaitu bahasan mengenai ekonomi, sosial politik dan keagamaan. Sedangkan hasil survei pada generasi usia muda usia 15-24 tahun memiliki kecenderungan menyukai topik perbincangan terkait dengan film, olahraga, musik. Dan teknologi. Dengan demikian teknologi internet yang mempunyai banyak hiburan dipercaya akan menjadi kebutuhan pokok bagi generasi millennial. Hal ini didasari berdasarkan survei yang ada bahwa generasi usia 15-24 dinyatakan bahwa menjadi kelompok penduduk dengan konsumsi internet lebih tinggi dari pada generasi yang lebih tua. ${ }^{35}$ Adapun riset lebih lanjut menyatakan bahwa generasi millennial dalam tren tahun 2020 akan mencapai 34,0\%, atau setara dengan 84 juta jiwa penduduk. Kondisi tersebut memunculkan konsekuensi tersendiri atas perilaku dan karakter mereka yang tentu berbeda dengan generasi-generasi sebelumnya. ${ }^{36}$

Kecenderungan generasi milenial yang tidak lepas dengan teknologi, menyebabkan generasi milenial tidak dapat dipisahkan oleh alat dan media berbeasis teknologi. Sehingga hal ini

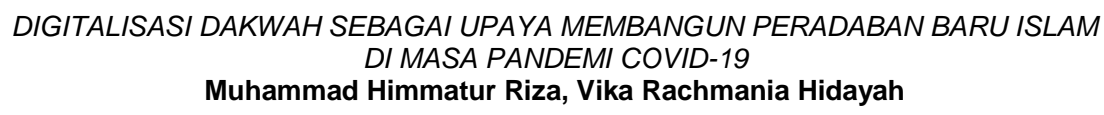




\section{Fastabiq: Jurnal Studi Islam \\ ISSN 2723-0228}

Vol. 2 No. 1 Bulan Juni Tahun 2021

menyebabkan generasi millennial akan menjadi lebih kreatif dalam mencari sebuah konten-konten untuk terus di update pada media sosialnya. Menyikapi hal tersebut, perlu sekali kebijaksanaan para pengguna media sosial dalam mengunakan internet dan teknologi sesuai dengan kebutuhan yang ada. Dengan demikian, dakwah dapat dilaksanakan dengan memanfaatkan teknologi sebagai media untuk menyampaikannya. Konteks dakwah yang dilaksanakan harus bersifat ramah dan bijaksana, sehingga Islam dapat dikenal dengan agama yang ramah tidak radikal. Salah satunya adalah ketika hal ini berimplikasi pada sebagian besar masyarakat muslim kontemporer di Indonesia yang memanfaatkan internet sebagai pembelajaran Islam. ${ }^{37}$ Pada akhirnya, peran generasi millennial pada penyebaran dakwah menggunakan metode digital sangat diperlukan. Mengingat banyaknya generasi millennial saat ini, menjadikan peluang untuk terus menebarkan nilai-nilai kehidupan kepada sesame. Perkembangan teknologi yang semakin pesat dan penetrasinya yang semakin cepat menjadikan mudahnya tersebarnya sebuah informasi pada sosial media.

Melakukan dakwah di era sekarang merupakan perkara yang sangat penting untuk terus memberikan nilai-nilai islami dalam kehidupan sehari-hari. Namun jika kita merujuk pada perkembangan IPTEK, maka generasi millennial lah yang harusnya mengambil peran penting dalam penyebaran dakwah. Namun hal tersebut pastinya terdapat tantangan dan peluang bagi generasi millennial dalam berdakwah, hal ini dikarenakan dakwah yang akan disampaikan harus memenuhi dan menyeimbangkan nilai kehidupan berdasarkan konteks yang sesuai. Terlebih pada tantangan yang akan dihadapi oleh pendakwah dari generasi millennial adalah dengan melihat beberapa prespektif diantaranya prespektif perilaku, prespektif transaksional dan prespektif transmisi. Sedangkan peluang yang didapatkan pada era yang serba digital ini adalah perkembangan IPTEK dapat mendukung penyebaran nilai-nilai keislaman dalam berdakwah. Penggunaan akun media sosial (Facebook, Twitter, Instagram, Youtube dII) dalam berdakwah merupakan langkah yang solutif dalam era globalisasi ini. ${ }^{38}$

Penyelarasan tekstual dan kontekstual menjadikan hal yang penting dan juga momok yang menghantui umat muslim. Karena keduanya harus berjalan secara beriringan yaitu dengan menaati ajaran-ajaran islam yang tekstual sesuai dengan tuntuttan teks-teks agama, juga harus meliat bagaimana kondisi perkembangan kemanusiaan yang terjadi dalam kehidupan masyarakat. Menempatkan posisi pada dua tempat tersebut tidaklah mudah untuk semua pihak. Menjadi muslim yang baik dan dapat menyesuaikan diri terhadap perubahan merupakan tantangan umat muslim masa kini agar dapat terus mempertahankan eksistensi Islam yang ramah. Sehingga masalah tersebut dapat dirumuskan dengan bahasa yang lebih lugas, yakni bagaimana menjadi otentik, sekaligus menjadi modern. ${ }^{39}$

Islam harus mampu menunjukan wajah yang ramah nan sejuk sehingga dalam menyerukan ajakan kebaikan yang kembali dalam nilai-nilai keislaman tidak menjadikan umat menjadi kaku dan stagnan. Selama ini wajah Islam yang sering ditampilkan dalam media acapkali memposisikan islam sebagai gerakan terorisme, sehingga muncul kredo Islam is a teoririst. Hal ini menjadikan pentingnya da'i belajar mengenai retorika dalam melaksanakan dakwah dalam perkembangan 


\section{Fastabiq: Jurnal Studi Islam \\ ISSN 2723-0228}

Vol. 2 No. 1 Bulan Juni Tahun 2021

teknologi digital saat ini. Dengan demikian, perkembangan teknologi menjadi peluang emas untuk terus mempropaganda nilai-nilai Islam yang rahmatan lil alamin agar dapat bersaing dengan hegemoni Barat yang sudah merasuk dalam pemikiran dan ideology umat manusia lebih khususnya umat Islam.

Islam tidak menghambat umatnya untuk dapat maju dan berkembang jika kita melihat secara teologisnya. Bahkan Islam sangat mendorong untuk menjadi umat yang terbaik di muka bumi. Melihat dasar teologisnya, sehingga menjadikan umat Islam memerlukan bekal yang mumpuni perihal pengetahuan dan praktik penguasaan teknologi bagi para dai. Perlunya mengubah paradigm tentang anggapan bahwa da'i hanya pandai berbicara soal agama saja namun telah gagap dalam perkembangan teknologi. Spatutunya, da'i mampu mengasah keterampilan dalam berselancar di media sosial guna berdakwah. Peran pemerintah menanggapi hal ini pun sangat dibutuhkan untuk dapat memfasilitasi para da'i agar dapat terselenggarakannya technological education, agar dakwah Islam yang disyiarkan lebih berwarna dan modern.

Era modern sekarang dibutuhkan spirit untuk masyarakat dengan memandang Islam sebagai nilai dan pandangan hidup. Sehingga sudah menjadi hal yang harus dilakukan bahwa teknologi informasi mengakomodir perkembangan peradaban umat Islam sekarang ini. Perwujudan dari agamanya merupakan gaya suatu peradaban yang menjadikan agama menjadi sumber utama. Kehadiran Islam pada peradaban dunia ini dapat dipertahankan dengan mempertahankan eksistensi melalui digitalisasi dakwah. Seberapa jauh umat Islam dapat memanfaatkan teknologi, maka akan menentukan seberapa maju umat Islam. Hal itu tergantung pada kemampuan umat Islam dalam membuka peluang dan relasi kebudayaan dengan teknologi. Dengan demikian, digitalisasi dakwah dapat dibangun menjadi peradaban baru Islam di era pendemi Covid-19 jika mana umat Islam secara internasional mempunyai identitas karya-karya yang inovasi.

\section{SIMPULAN}

Perkembangan teknologi digital yang semakin pesat menjadi sebuah peluang emas untuk menyampaikan dakwah islami. Digitalisasi dakwah sebagai cara membangun peradaban baru di era covid-19 dapat dilaksanakan melalui akun media sosial seperti Instagram, Facebook, Youtube, Twitter, dan akun media lainnya. Digitalisasi dakwah merupakan langkah untuk menyebarkan nilainilai Islam dengan memanfaatkan perkembangan IPTEK. Dalam melaksanakan dakwah, seorang da'i haruslah menunjukan wajah islam yang ramah dan merangkul untuk semuanya. Sehingga pentingnya pengetahuan yang mumpuni, pengembangan soft skill dialektika dan penguasaan teknologi oleh seorang da'i sangat diperlukan untuk dapat melaksanakan kegiatan dakwah secara digital dengan baik dan ramah. Generasi baru saat ini lebih menyukai membuka media sosial disaat waktu-waktu luang. Sehingga digitalisasi dakwah diperlukan dengan membuat konten kreatif seperti desain grafis dan juga video dakwah menarik dengan persoalan anak muda yang diunggah di media digital seperti dia kun media sosial. 


\section{Fastabiq: Jurnal Studi Islam \\ ISSN 2723-0228}

Vol. 2 No. 1 Bulan Juni Tahun 2021

\section{ENDNOTES}

1 Y. Zhao, \& J. Watterston, "The changes we need: Education post COVID-19," Journal of Educational Change, Vol. 22 No. 1, 2021, 3-12.

2 S. Z. Qudsy, "Pesantren Online: Pergeseran Otoritas Keagamaan Di Dunia Maya," Living Islam: Journal of Islamic Discourses, Vol. 2 No. 2, 2019. Hal. 169-187. Lihat juga Nugraha, Firman, "Model dan Etika Penyuluhan Agama di Internet", Tatar Pasundan: Jurnal Diklat Keagamaan, Vol.9 No. 25, 2015.

3 Salman Yoga S, "Dakwah Di Internet: Konsep Ideal, Kondidi Objektif Dan Prospeknya," Jurnal Al-Bayan, Vol. 22 No. 31, 2015. Hal. 64.

4 Diah Aryani Syahrial Dwi Putra, Tiara Fanny Eldiana, "Model Pengembangan Aplikasi Mobile E-Dakwah Di Masa Pandemi Covid-19 Dengan Metode Prototyping," Journal of Information System, Informatics and Computing, Vol. 4 No. 1, Juni 2020. Hal. 116.

5 Joko Tri Haryanto, "Perkembangan Dakwah Sufistik Prespektif Tasawuf Kontemporer," Jurnal Addin, Vol. 8 No. 2, 2014. Hal. 271.

6 F. Mala, "E-Dakwah: Tinjauan Awal Kontestasi Islam, Dakwah, Dan Internet," Dakwatuna: Jurnal Dakwah Dan Komunikasi Islam, Vol. 3 No. 1, 2017. Hal. 13.

7 Abdul Basit, Dakwah Antar Individu Teori Dan Aplikasi, Yogyakarta: Grafindo Litera Media, 2008.

8 Departemen Agama RI, Alquran Dan Terjemahnya, Surabaya: Mahkota, 1987. Hal. 54.

9 Departemen Agama RI, Alquran Dan Terjemahnya, Surabaya: Mahkota, 1987. Hal. 54.

10 Muhidin, Dakwah Dalam Perspektif Al-Quran, Bandung: Pustaka Setia, 2002. Hal. 19.

11 Abdul Basit, "Dakwah Cerdas Di Era Modern," Jurnal Komunikasi Islam, Vol. 3 No. 1, 2013. Hal. 82.

12 Abdul Basit, Dakwah Antar Individu Teori Dan Aplikasi, Yogyakarta: Grafindo Litera Media, 2008.

13 Muhammad Ghalab, Al-Tashawuf Al Muqarin, Makkah: Maktabah An Nahdhah, n.d.

14 Barmawie Umarie, Sistematika Tasawuf, Solo: Siti Syamsiyah, 1966.

15 Elmansyah, "Dakwah Sufistik Di Era Digital," Jurnal Al-Hikmah, Vol. 10 No. 1, 2016. Hal. 60.

16 Elmansyah, "Dakwah Sufistik Di Era Digital," Jurnal Al-Hikmah, Vol. 10 No.1, 2016. Hal. 63.

17 Wahyu Budiantoro, "Dakwah Di Era Digital," Jurnal KOMUNIKA, Vol. 11 No. 2, Juli Desember 2017. Hal. 269.

18 Wahyu Budiantoro, "Dakwah Di Era Digital," Jurnal KOMUNIKA, Vol. 11 No. 2, Juli Desember 2017. Hal. 270.

19 Departemen Agama RI, Al-Qur'an Dan Terjemahnya, Jakarta: Yayasan Penyelenggara Penterjemah / Penafsir Al-Qur'an, 1971. Hal. 63.

20 Juhari, "Perubahan Sosial Dalam Prespektif Dakwah," Jurnal Al-Bayan, Vol. 21 No. 32, Juli - Desember 2015. Hal. 37.

21 Wiryo Setiana, "Revitalisasi Dakwah Dalam Menghadapi Dampak Budaya Global Di Indonesia," Jurnal IImu Dakwah, Vol. 5 No. 18, 2011. Hal. 494.

22 Wiryo Setiana, "Revitalisasi Dakwah Dalam Menghadapi Dampak Budaya Global Di Indonesia," Jurnal IImu Dakwah, Vol. 5 No. 18, 2011. Hal. 495.

23 Wahyu Budiantoro, "Dakwah Di Era Digital," Jurnal KOMUNIKA, Vol. 11 No. 2, Juli Desember 2017. Hal. 271.

24 Muhammad Sulthon, Menjawab Tantangan Zaman Desain IImu Dakwah Kajian Ontologis, Epistemologis, Dan Aksiologis, Yogyakarta: Pustaka Pelajar, 2003. Hal. 26.

25 Sakareeya Bungo, "Pendekatan Dakwah Kultural Dalam Masyarakat Plural," Jurnal Dakwah Tabligh, Vol. 15 No. 2, Desember 2014. Hal. 214. 


\section{Fastabiq: Jurnal Studi Islam \\ ISSN 2723-0228}

Vol. 2 No. 1 Bulan Juni Tahun 2021

26 T.S. Robiah, "Analysis of Rampa Bedug Arts as Media on Da'wa in Banten," Jurnal Bimas Islam, Vol. 6 No. 3, 2013. Hal. 462.

27 Cucu, "Manajemen Dakwah Rasulullah: Analisis Dakwah Nabi Di Kota Mekah," Tadbir: Jurnal Manajemen Dakwah, Vol. 1 No. 2, Desember 2016. Hal. 31.

28 Mubasyaroh, "Karakteristik Dan Strategi Dakwah Rasulullah Muhammad SAW Pada Periode Makkah," At-Tabsyir: Jurnal Komunikasi Penyiaran Islam, Vol. 3 No. 2 Desember 2015. Hal. 401.

29 Ashadi, "Dakwah Wali Songo Pengaruhnya Terhadap Perkembangan Perubahan Bentuk Arsitektur Mesjid Di Jawa (Studi Kasus: Mesjid Agung Demak)," NALARS: Jurnal Arsitektur, Vol. 12 No. 2, Juli 2013. Hal. 1.

30 Yuliatun Tajuddin, "Walisongo Dalam Strategi Komunikasi Dakwah," Addin: Media Dialektika IImu Islam, Vol. 8 No. 2, 2014. Hal. 369.

31 Dwi Kurniasih, "Dakwah Milenial Era Digital: Analisis Linguistik Kognitif Pada Lagu Balasan Jaran Goyang," Al-Balagh: Jurnal Dakwah Dan Komunikasi, Vol. 4 No. 2, Juli Desember 2019. Hal. 246.

32 Yanuar Surya Putra, "Theoritical Review: Teori Perbedaan Generasi," Jurnal Among Makarti, Vol. 9 No. 2, 2017. Hal. 125.

33 Hasanuddin Ali \& Lilik Purwandi, Wajah Muslim Indonesia, Jakarta: Islami(dot)co, 2019.

34 Yanuar Surya Putra, "Theoritical Review: Teori Perbedaan Generasi," Jurnal Among Makarti, Vol. 9 No. 2, 2017. Hal. 129.

35 Ali Hasanuddin, "Generasi Millennial Indonesia: Tantangan Dan Peluang Pemuda Indonesia," Alvara, 2015, https://alvara-strategic.com/generasi-millennial-indonesiatantangan-dan-peluang-pemuda-indonesia/.

36 Purwandi, Wajah Muslim Indonesia.

37 Moch. Fakhruroji, "Muslims Learning Islam on the Internet," in Handbook of Contemporary Islam and Muslim Lives, Springer References, n.d. Hal. 4.

38 Dwi Kurniasih, "Dakwah Milenial Era Digital: Analisis Linguistik Kognitif Pada Lagu Balasan Jaran Goyang," Al-Balagh: Jurnal Dakwah Dan Komunikasi, Vol. 4 No. 2, Juli Desember 2019. Hal. 248.

39 Wahyu Budiantoro, "Dakwah Di Era Digital," Jurnal KOMUNIKA, Vol. 11 No. 2, Juli Desember 2017. Hal. 277. 


\section{Fastabiq: Jurnal Studi Islam \\ ISSN 2723-0228}

Vol. 2 No. 1 Bulan Juni Tahun 2021

\section{REFERENSI}

Aryani, Diah, Syahrial Dwi Putra, Tiara Fanny Eldiana, 2020. "Model Pengembangan Aplikasi Mobile E-Dakwah Di Masa Pandemi Covid-19 Dengan Metode Prototyping," Journal of Information System, Informatics and Computing, Vol. 4 No. 1.

Basit, Abdul, 2013 . "Dakwah Cerdas Di Era Modern," Jurnal Komunikasi Islam, Vol. 3 No. 1.

Basit, Abdul, 2008, Dakwah Antar Individu Teori Dan Aplikasi, Yogyakarta: Grafindo Litera Media.

Budiantoro, Wahyu, 2017. "Dakwah Di Era Digital," Jurnal KOMUNIKA, Vol. 11 No. 2, Juli Desember.

Bungo, Sakareeya, 2014. "Pendekatan Dakwah Kultural Dalam Masyarakat Plural," Jurnal Dakwah Tabligh, Vol. 15 No. 2, Desember.

Cucu, "Manajemen Dakwah Rasulullah: Analisis Dakwah Nabi Di Kota Mekah," Tadbir: Jurnal Manajemen Dakwah, Vol. 1 No. 2, Desember 2016. Hal. 31.

Departemen Agama RI, 1971, Al-Qur'an Dan Terjemahnya, Jakarta: Yayasan Penyelenggara Penterjemah / Penafsir Al-Qur'an.

Departemen Agama RI, 1987, Alquran Dan Terjemahnya, Surabaya: Mahkota.

Kurniasih, Dwi, 2019. "Dakwah Milenial Era Digital: Analisis Linguistik Kognitif Pada Lagu Balasan Jaran Goyang," Al-Balagh: Jurnal Dakwah Dan Komunikasi, Vol. 4 No. 2.

Elmansyah, 2016. "Dakwah Sufistik Di Era Digital," Jurnal Al-Hikmah, Vol. 10 No.1.

Ghalab, Muhammad, Al-Tashawuf Al Muqarin, Makkah: Maktabah An Nahdhah, n.d.

Haryanto, Agus Tri, "Riset: Ada 175,2 Juta Pengguna Internet di Indonesia". Detiknet (https://m.detik.com/inet/cyberlife/d-4907674/riset-ada-1752-juta-pengguna-internet-diindonesia) diakses pada hari Senin, 11 Januari 2021 pukul 11:07 WIB

Haryanto, Joko Tri, "Perkembangan Dakwah Sufistik Prespektif Tasawuf Kontemporer," Jurnal Addin, Vol. 8 No. 2, 2014.

Ali, Hasanuddin \& Lilik Purwandi, 2019, Wajah Muslim Indonesia, Jakarta: Islami(dot)co.

Hasanuddin, Ali, "Generasi Millennial Indonesia: Tantangan Dan Peluang Pemuda Indonesia," Alvara, 2015, https://alvara-strategic.com/generasi-millennial-indonesia-tantangan-dan-peluangpemuda-indonesia/.

Juhari, 2015. "Perubahan Sosial Dalam Prespektif Dakwah," Jurnal Al-Bayan, Vol. 21 No. 32.

Mala, F., 2017. "E-Dakwah: Tinjauan Awal Kontestasi Islam, Dakwah, Dan Internet," Dakwatuna: Jurnal Dakwah Dan Komunikasi Islam, Vol. 3 No. 1.

Fakhruroji, Moch., "Muslims Learning Islam on the Internet," in Handbook of Contemporary Islam and Muslim Lives, Springer References, n.d.

Mubasyaroh, 2015. "Karakteristik Dan Strategi Dakwah Rasulullah Muhammad SAW Pada Periode Makkah," At-Tabsyir: Jurnal Komunikasi Penyiaran Islam, Vol. 3 No. 2. Hal. 401.

Muhidin, 2002, Dakwah Dalam Perspektif Al-Quran, Bandung: Pustaka Setia.

Nugraha, Firman, 2015. "Model dan Etika Penyuluhan Agama di Internet", Tatar Pasundan: Jurnal Diklat Keagamaan, Vol.9 No. 25.

Prabowo, Nugroho Agung, Purwono Hendradi, Bambang Pujiarto, 2019. "Kerangka Model Aplikasi EDakwah Pengembangan Kaderisasi Pada Pengurus Daerah Muhammadiyah Kota Magelang," IJNS - Indonesian Journal on Networking and Security, Vol. 8 No. 3.

Qudsy, S. Z., 2019. "Pesantren Online: Pergeseran Otoritas Keagamaan Di Dunia Maya," Living Islam: Journal of Islamic Discourses, Vol. 2 No. 2.

Robiah, T.S., 2013. "Analysis of Rampa Bedug Arts as Media on Da'wa in Banten," Jurnal Bimas Islam, Vol. 6 No. 3.

S, Salman Yoga, 2015 . "Dakwah Di Internet: Konsep Ideal, Kondidi Objektif Dan Prospeknya," Jurnal Al-Bayan, Vol. 22 No. 31.

Setiana, Wiryo. 2011. "Revitalisasi Dakwah Dalam Menghadapi Dampak Budaya Global Di Indonesia," Jurnal IImu Dakwah, Vol. 5 No. 18. 


\section{Fastabiq: Jurnal Studi Islam \\ ISSN 2723-0228}

Vol. 2 No. 1 Bulan Juni Tahun 2021

Sulthon, Muhammad, 2003, Menjawab Tantangan Zaman Desain IImu Dakwah Kajian Ontologis, Epistemologis, Dan Aksiologis, Yogyakarta: Pustaka Pelajar.

Umarie, Barmawie, 1966, Sistematika Tasawuf, Solo: Siti Syamsiyah.

Putra, Yanuar Surya. 2017. "Theoritical Review: Teori Perbedaan Generasi," Jurnal Among Makarti, Vol. 9 No. 2.

Tajuddin, Yuliatun, 2014 . "Walisongo Dalam Strategi Komunikasi Dakwah," Addin: Media Dialektika IImu Islam, Vol. 8 No. 2.

Zhao, Y, \& J. Watterston, 2021. "The changes we need: Education post COVID-19," Journal of Educational Change, Vol. 22 No. 1. 